\title{
Analysis on Corporation Property Rights Institution of Privately-run Education Agencies
}

\author{
Wei Xu \\ Shenzhen Broadcasting \& Television University \\ Shenzhen 518000, China \\ E-mail: szddzs@163.com
}

Received: October 13, 2011

Accepted: November 15, $2011 \quad$ Published: December 1, 2011

doi:10.5539/ass.v7n12p245

URL: http://dx.doi.org/10.5539/ass.v7n12p245

\begin{abstract}
After Law on Promotion of Privately-run Schools in PRC being issued, many scholars have focused on studies of corporation property rights institution of privately-run education agencies. This paper analyzes corporation property rights institution of privately-run education agencies around the rights of possessing, occupying, benefiting and disposing.
\end{abstract}

Keywords: Privately-run education agencies, Corporation property rights institution, Law on promotion of privately-run schools

\section{Introduction}

Property rights institution is a system of legal norms to define and adjust the property rights. Around the rights of possessing, occupying, benefiting and disposing, I study corporation property rights institution of privately-run education agencies. The study is useful in managing privately-run education agencies and promoting their development.

\section{Definition of privately-run education agencies and their property rights}

In fact, the definition of privately-run education is a legal problem while there are many different opinions in theory. Article II (If there are no other special instructions, the articles below belong to Law on Promotion of Privately-run Schools in PRC) stipulates that, "This law shall be applicable to activities conducted by public organizations or individuals, other than State organs, to establish and run schools and other institutions of educations with non-governmental financial funds, which are geared to the need of society." Schools and other institutions of educations here are interpreted in Article 11, "The establishment of privately-run schools that provide education for academic credentials, pre-school education, training for preparing self-study examinations and other cultural education shall be subject to examination and approval by the administrative departments for education under the people's governments at or above the county lever within the limits of their powers defined by the State; the establishment of a privately-run school that mainly provides training for vocational skills, including training for vocational qualification, shall be subject to examination and approval by the administrative department for labor and social security under the people's government at or above the county level within the limits of its powers defined by the State, which shall send a duplicate of the approval document to the administrative department for education at the same lever for the record." The classification of privately-run education agencies should be exhaustive classification because the establishment of privately-run education agencies must be approved. Moreover, privately-run education belongs to public welfare project and is one part of education. Private training institutions which are registered by industrial and commercial administrative departments are excluded from privately-run education agencies. So, privately-run education agencies include privately-run academic schools, non-academic schools and other short-term non-academic professional training institutions which are public welfare.

Property ownership of privately-run education agencies refers to property rights of privately-run education agencies which are narrow meaning of property rights (Property ownership in this paper refers to the same meaning). Property ownership of privately-run education agencies includes the rights of possessing, occupying, benefiting and disposing. 
Property rights reflect certain economic and social relations. Property rights reflect relationship among people caused by existence and occupy of objects rather than the relations between people and objects. Property rights system is the system of defining, regulating and adjusting property rights. It defines who owns, who dominates, who benefits and who loses via law. In economic activities, joint-stock company is the typical form of property rights system and has a complete institutional system which includes establishment, assignment, control and other seven institutions. Privately-run education agencies are a kind of organizations owning property rights which are very different with enterprises so that property rights systems of privately-run education agencies could not be copied from the property rights systems of enterprises. From provisions of Law on Promotion of Privately-run Schools, the property rights system of privately-run education agencies has preliminary constituted a system having its own characteristics and is a system focusing on corporation property rights and surrounding possessing, occupying, benefiting and disposing properties.

\section{Analysis of property rights institution of privately-run education agencies}

\subsection{Possessing rights}

There are four kinds of opinions in research of property possessing rights of privately-run education agencies. The first opinion thinks that privately-run education agencies are public welfare, the same as pubic education institutions. And properties of privately-run schools should belong to state, the same as public schools. The second opinion is that, from business views and logics, the investors are the owners and privately-run schools should belong to the person or enterprise who invests. The third opinion thinks that the ownership problem should not be discussed firstly and the person or enterprise who establishes privately-run schools should be permitted to recoup investment and earn interest after the schools operate normally. The fourth opinion is that privately-run schools still belong to the person or enterprise who establishes privately-run school after the investment and interest are earned because privately-run schools are value-added investment.

The opinions in Law on Promotion of Privately-run Schools are different form the above opinions and stipulate from possessing rights of organizers and ownership rights of privately-run education agencies. Firstly, the law does not affirm that the establisher has property processing rights of investing into privately-run agencies positively and affirms that investors have processing rights for their investment while the establisher is changed. It means that, the property of privately-run education agencies does not belong to the establishers. Secondly, privately-run education agencies have corporation property rights. The law has comprehensive provisions for that, "Privately-run schools shall enjoy property rights of the legal persons in respect of the assets provided by investors to privately-run schools, State-owned assets, donated property and school accumulation. During the period of existence of privately-run schools, all the assets shall, in accordance with law, be managed and used by the schools, and no organization or individual may take illegal possession of them. No organization or individuals may, in violation of laws or regulations, collect any fees from privately-run institutions of education."

China's current laws classify corporation as enterprise corporation, public institution corporation, social group corporation, and private non-enterprise corporation. The organizational form of privately-run education agencies decides that they could not be registered as enterprise corporations and social group corporations and they only could be registered public institution corporations or private non-enterprise organization corporations. Interim Regulation on the Registration of Public Institutions stipulates that, "Public institution corporations are social service organizations which are organized by government or other organizations with state-owned assets for social welfare and which engage in education, science and technology, culture, health and other activities." Though privately-run education agencies accord with the characteristics of action content and action range of public institution corporation, the investment source of privately-run education agencies does not accord with legal conditions of public institution corporation and behavior subject does not fully comply with the provisions. Therefore, privately-run education agencies should not be regarded as public institution corporation. Interim Regulation on the Registration of Privately-run and Non-enterprise Organizations stipulates that, "Privately-run and non-enterprise organizations refer to the social organizations which are founded with non- state owned assets by enterprises, public institutions, social groups, other social organizations or citizen own selves and which engage in non-profit social service activities. Hereby, privately-run education agencies are only regarded as private non-enterprise corporation.

The classification confirmation of privately-run educational agencies determines two questions. The first is that privately-run education agencies are non-profit as non-enterprise organizations. The second is that privately-run educational agencies have corporation property rights as non-enterprise organizations. The confirmation of corporation property rights of privately-run educational agencies has two sides of prominent meanings. Firstly, 
the rule of who invests who benefits is the basic rule affirming property rights in Civil Law. The investor should have benefit rights if the investor has the possessing rights for privately-run education agencies. However, the investor should not have possessing rights, benefit rights and even property rights while the property rights of privately-run education agencies is non-enterprise corporation property rights. That is, non-enterprise organizations have not specific property owners and their property should be possessed by any owners of property elements. Secondly, the characteristic of non-profit of privately-run education agencies decides that the surplus of privately-run education agencies could not be distributed as profit by investors, operators and other members of privately-run education agencies. All returns should be possessed and dominated by privately-run education agencies and should not be shifted outside privately-run education agencies in duration. So non-profit organizations establishing privately-run organization ensures the characteristics of non-profit of privately-run education agencies at the basic level of property rights institution, guarantees property of privately-run education agencies as social public property, and provides conditions for establishing privately-run education agencies with non-profit aim.

So the confirmation of property rights and classification for corporation rights stipulated by Law on Promotion of Privately-run Schools keeps in accordance with the provision 'Should not establish privately-run education agencies aiming to profit' stipulated by Education Law. It also reflects the legislation spirit that privately-run education belongs to public welfare and is a part of socialism education.

\subsection{Benefit rights}

Benefit rights are the benefiting rights of civil subjects based on property. The property rights of the subjects of rights are the basic rights to get directly benefits and indirect benefits. However, the benefit rights for investors of privately-run education agencies are different because of the confirmation of corporation property rights of privately-run education agencies. Article 51 include this meaning, "After the cost of a privately-run school is deducted, the funds for its development are withheld and the sum of money for other necessary expenses is drawn in accordance with the relevant regulations of the State, the fund providers may obtain a reasonable amount of requital from the cash surplus of the school. Specific measures for obtaining reasonable amounts of requital shall be formulated by the State Council."

Firstly, the relation between profits of privately-run education agencies and 'Should not aim to profit' needs to clear. Though Education Law stipulates that 'Should not establish privately-run education agencies aiming to profit', 'not aiming to profit' is not equal to 'Should not profit'. Because privately-run education agencies are non-profit organizations, anyone inside privately-run education agencies could not take profits of schools and the surplus of privately-run education agencies could not be distributed personally and owe to oneself. Moreover, pursuing profit maximization could not be regarded as incentives to develop privately-run education agencies. However, it is not equal to that privately-run education agencies could not have profits. The profits should stay inside to develop.

Secondly, reasonable return is encouraging and is not an embodiment of benefit rights of investors. Benefit rights are based on that the property belongs to investors and depend on investment value adding. If the investors do not have property rights for their investment of privately-run education agencies, they do not have benefit rights whether their investment increase in value. The characteristics of corporation property rights of privately-run education agencies decides that the investors do not have possessing rights for their investment so that reasonable return only can be encouraging.

The provisions of return mode in Law on Promotion of Privately-run Schools are general. How to hold in performing is assuredly difficult because there are all kinds of specific and complicated situations. This paper considers that some key problems should mainly be settled. The first problem is the economic characteristics. From economics angel, investors should be rewarded for their investment. But the reward should be price of capital and belong to costs of privately-run education agencies and the reward is not the profit of privately-run education agencies. So-called reasonable should be considered whether capital is value-added. The specific situations whether capital is value-added decide the amount of the reward and the degree of reasonable. Then, the reward has a scientific principle. The second problem is the law characteristics. From the property law relations brought by investment of investors between investors and privately-run education agencies, the relations are actually the relation between creditors and debtors. The investors as debtors can only get contract revenue stipulated by contract and the amount of revenue is determined at the beginning of the investment. Government should regulate a maximum return on investment via legislation. Professor Li Yining indicates that it is comparatively reasonable that the amount of return on investment does not exceed the interest on government bonds over the same period. The third is cost characteristics. Cost accounting of school operation 
is very complex and Cost is difficult to be drawn legally resembling to develop fund and other necessary expenses in accordance with relevant state regulations. Sometimes reasonable return only has legal sense and is difficult to play a role in practice. It reflects in that non-profit and privately-run education agencies often distribute operating profits directly and indirectly in schools operating through raising wages and benefits in advance, and improving house conditions, increasing the amount of medical insurance of staffs. These expenses are counted in operating costs so that privately-run education agencies have certain benefit rights. The difference between benefit rights of privately-run education agencies and those of for-profit privately-run education agencies is the difference of amount and not the difference between with and without. The benefit right of privately-run education agencies are difficult to control and should not be controlled by state law. Though specific composition of for-profit and non-profit education agencies is decided by law system of state, they have more academic autonomy and more operation and control rights. That is, the provision of reasonable return is usually more than mere form of law.

\subsection{Occupying rights}

Corporation property rights of privately-run education agencies decide that occupying rights are entitled to privately-run education agencies. But the entitled rights of investors are not necessary for corporation institution. Therefore, Law on Promotion of Privately-run Schools describes that, "During the period of existence of privately-run schools, all the assets shall, in accordance with law, be managed and used by the schools, and no organization or individual may take illegal possession of them." That is reflected in three sides. The first is occupying rights of privately-run schools. They include deciding forms of decision-making bodies of the school, choosing internal management system of schools, appointing and dismissing staff members independently, deciding on the size and the wage standards of the teachers and staff members, managing and occupying schools assets independently, deciding school spending and charge criterion, and etc.. The second is occupying rights of investors. They reflect mainly about functions and powers of the board of directors of a school. The rights include appointing and dismissing the principal, amending the articles of association of the school and formulate rules and regulations of the school, making development plans and approve annual work plans, raising funds for running the school, and examine and verify the budgets and final accounts, deciding on the size and the wage standards of the teachers and staff members, deciding on the division. merging and termination of the school, and etc. The third is occupying rights of the principle. The principal is in charge of education, teaching and administration of the school, and exercise the following functions and powers. The rights include carrying out the decisions made by the executive council, board of directors or any other form of decision-making body, putting into execution the development plans, draw up the annual work plans and financial budgets, and formulate the rules and regulations of the school, appointing and dismissing staff members of the school, and give rewards and impose punishments, and etc.

\subsection{Disposing rights}

Disposing rights are the rights to dispose property for the subjects of rights in the range law permitted. Corporation property rights of privately-run education agencies have decisive meanings in the problem of property disposing rights of privately-run education agencies. These reflect in two sides of property disposing in normal operating and financial settlement after terminated.

Article 36 stipulates that, "During the period of existence of privately-run schools, all the assets shall, in accordance with law, be managed and used by the schools, and no organization or individual may take illegal possession of them. No organization or individuals may, in violation of laws or regulations, collect any fees from privately-run institutions of education." It affirms that property disposing rights of privately-run education agencies should be exercised by privately-run education agencies and do not belong to investors. Though investors have fixed compact benefits for their investment, they do not have disposing rights. Investors could not withdraw their investment and mortgage their investment so long as privately-run education agencies are still operating.

Concerning financial settlement after privately-run education agencies terminated, Law on Promotion of Privately-run Schools stipulates that the remaining property of a privately-run school shall be disposed of in accordance with the provisions of relevant laws and administrative regulations. The provision ensures corporation rights of privately-run education agencies. Also the provision makes fundamental regulations for benefits of investors in financial settlement. And withdrawal rights of investment for investors. Related legislation departments should further stipulate according to General Civil Law and Welfare Donations Law in the PRC while they constitute implementation measures because of complicated reality. 


\section{References}

Han, Yi. (2010). Problems of Property Ownership of Privately-run Education. CO-Operative Economy \& Science, 26(22): 42-43.

Huang, Mingxin. (2011). Contradictions of Law on Promotion of Privately-run Schools and Breakthrough. Journal of North China Electric Power University (Social Sciences), 16(1): 69-72, 78.

Li, Yining. (1998). Reading on Theory of the Education Industry. Educational Research, 20(9): 74-75.

Liu, Zhao, and Shen, Xiuqing. (2007). Interpretation of and Reflection over Law of the People's Republic of China on Promotion of Privately-run schools. Journal of Southwest Agricultural University (Social Science Edition), 5(1): 142-144.

Wang, Yuanyuan. (2004). Research on Profit Problem of Privately-run Education Agencies. Journal of Sichuan Normal University (Philosophy and Social Sciences), 31(1): 59-62. 